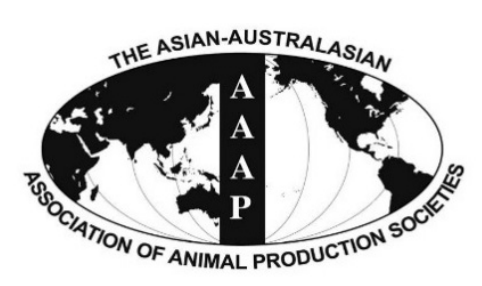

Open Access

Asian Australas. J. Anim. Sci.

Vol. 28, No. 10 : 1488-1495 October 2015

http://dx.doi.org/10.5713/ajas.15.0019

www.ajas.info

pISSN 1011-2367 elSSN 1976-5517

\title{
Effects of Post-harvest Storage Duration and Variety on Nutrient Digestibility and Energy Content Wheat in Finishing Pigs
}

\author{
P. P. Guo, P. L. Li, Z. C. Li, H. H. Stein ${ }^{1}$, L. Liu, T. Xia, Y. Y. Yang, and Y. X. Ma* \\ State Key Laboratory of Animal Nutrition, China Agricultural University, Beijing 100193, China
}

\begin{abstract}
This study was conducted to investigate the effects of post-harvest storage duration and wheat variety on the digestibility and energy content of new season wheat fed to finishing pigs. Two wheat varieties (Shi and Zhong) were harvested in 2013 and stored in the warehouse of the Fengning Pig Experimental Base at China Agricultural University for 3, 6, 9, or 12 mo. For each storage period, 12 barrows were placed in metabolism crates and allotted to diets containing 1 of the 2 wheat varieties in a randomized complete block design. The experimental diets contained $97.34 \%$ wheat and $2.66 \%$ of a vitamin and trace mineral premix. With an extension of storage duration from 3 mo to 12 mo, the gross energy (GE) and crude protein (CP) of the wheat decreased by $2.0 \%$ and $12.01 \%$, respectively, while the concentration of neutral detergent fiber (NDF), acid detergent fiber (ADF) and starch content increased by $30.26 \%, 19.08 \%$, and $2.46 \%$, respectively. Total non-starch polysaccharide, total arabinose, total xylose and total mannose contents decreased by $46.27 \%, 45.80 \%, 41.71 \%$, and $75.66 \%$, respectively. However, there were no significant differences in the chemical composition between the two wheat varieties with the exception of ADF which was approximately $13.37 \%$ lower in Shi. With an extension of storage duration from 3 mo to $12 \mathrm{mo}$, the digestible energy (DE), metabolizable energy (ME) content and the apparent total tract digestibility of GE, CP, dry matter, organic matter, ether extract, ADF and metabolizability of energy in wheat decreased linearly ( $<<0.01$ ) by $5.74 \%, 7.60 \%, 3.75 \%, 3.88 \%, 3.50 \%, 2.47 \%, 26.22 \%, 27.62 \%$, and $3.94 \%$, respectively. But the digestibility of NDF changed quadratically $(\mathrm{p}<0.01)$. There was an interaction between wheat variety and storage time for CP digestibility $(\mathrm{p}<0.05)$, such that the CP digestibility of variety Zhong was stable during 9 mo of storage, while the CP digestibility of variety Shi decreased ( $<<0.05)$. In conclusion, the GE, DE, and $\mathrm{ME}$ of wheat was stable during the first 3 to 6 mo of post-harvest storage, and decreased during the following 6 to 12 mo of storage under the conditions of this study. (Key Words: Digestibility, Digestible and Metabolizable Energy, Finishing Pigs, Post-harvest Storage, Wheat)
\end{abstract}

\section{INTRODUCTION}

Recently, wheat has become an attractive alternative energy source for swine production in China due to a shortage of corn and cost. Many factors influence the nutritional value of wheat (Gutierrez-Alamo et al., 2008), such as variety (Anderson and Bell, 1983), growing region (Dusel et al., 1997), growing season (Choct et al., 1999) and conditions of post-harvest storage (Kim et al., 2003).

New season wheat usually has a low, highly variable,

\footnotetext{
* Corresponding Author: Y. X. Ma. Tel: +86-10-6273-3588, Fax:+86-10-6273-3688, E-mail: mayongxi2005@163.com

${ }^{1}$ Department of Animal Sciences, University of Illinois, Urbana, IL 61801, USA.

Submitted Jan. 7, 2015; Revised Mar. 3, 2015; Accepted Apr. 10, 2015
}

metabolizable energy (ME) content (Choct and Hughes, 1997), and its detrimental effect on poultry performance has been reported in many studies (Huyghebaert and Schoner, 1999; Scott and Pierce, 2001). Several reports have shown that storage for more than 3 mo improved poultry performance (Choct and Hughes, 1999; Scott and Pierce, 2001). However, the changes in the nutritional value of new season wheat during storage have only been reported once in pigs (Cadogan et al., 2003). Cadogan et al. (2003) conducted an experiment on 10 different varieties of wheat both at the time of harvest and 10 mo post-harvest to investigate the effects of storage of wheat on piglet performance. After 10 mo of storage, the feed intake (of all 10 wheat varieties), and daily gain (9 of 10 wheat varieties) of the pigs were significantly higher, while feed conversion 
ratio decreased in 4 samples, increased in 4 samples and remained constant in 2 samples compared with new season wheat.

Previous studies have shown that the effect of storage on the apparent ME of cereal grains for poultry differed widely depending on variety with most wheat varieties responding positively (up to $3 \mathrm{MJ} / \mathrm{kg}$ ) to storage (Choct and Hughes, 2000). However, the effect of storage time on the available energy content of wheat for pigs has not been reported. We hypothesized that the available energy content of wheat for finishing pigs will increase with an extension of storage time and that the digestible energy (DE) and ME content of different wheat varieties may be affected differently by changes in the duration of storage. The aims of this study were to investigate the effects of post-harvest storage duration and wheat variety on the nutritional value of new season wheat for early finishing pigs.

\section{MATERIALS AND METHODS}

The experimental protocol used in this study was approved by the Institutional Animal Care and Use Committee of China Agricultural University (Beijing, China). This study was conducted in the Metabolism Laboratory of the Fengning Pig Experimental Base (Hebei, China).

\section{Wheat and diet composition}

Two newly harvested hard white winter wheat varieties, Zhong (variety 1) and Shi (variety 2), were sourced from Henan province during the 2012/2013 harvest season. Zhong and Shi are the two most commonly grown wheat varieties in China, and Henan Province is the main wheat growing region in the country. The two wheat varieties were sown in September, 2012 and harvested in June, 2013. The intact wheat grains were stored from July 2013 to July 2014 in a warehouse located at the China Agricultural University Fengning Pig Experimental Base (China). The warehouse was not air conditioned and the room temperature fluctuated with the change in seasonal temperatures to simulate typical storage conditions for grain. The variations in temperature and humidity in the Fengning Pig Experimental Base over the course of the experiment are shown in Table 1.

Following 3, 6, 9, or 12 mo of storage, sub-samples of the 2 wheat varieties were ground through a $2 \mathrm{~mm}$ screen using a hammer mill. Diet composition and nutrient concentration of the experimental diets for the 4 storage durations are presented in Table 2. All diets were fed in meal form. Wheat was included as the sole energy and protein source in the diet and vitamins and minerals were added to meet or exceed requirements for growing pigs (NRC, 1998).

\section{Animals and experimental design}

Forty eight barrows (Duroc $\times$ Landrace $\times$ Yorkshire), with an initial body weight (BW) of $59 \pm 0.98 \mathrm{~kg}$, were randomly allotted to a $2 \times 4$ factorial arrangement involving 2 wheat varieties (Shi and Zhong), and 4 levels of storage time $(3,6$, 9, or 12 mo ). At each storage time, 12 pigs were blocked by initial BW and allocated to 1 of the 2 wheat varieties diets. Pigs were fed at 3\% of their BW daily determined one day before the beginning of the trial. The room temperature was maintained at $20 \pm 1^{\circ} \mathrm{C}$. Pigs were housed individually in stainless steel metabolism crates $\left(1.4 \times 0.7 \times 0.6 \mathrm{~m}^{3}\right)$. Pigs were allowed ad libitum access to water through a nipple waterer located at the side of the crate.

\section{Sample collection}

The daily feed allotment was divided into two equal meals and was fed at 08:00 and 15:00 h. After a $7 \mathrm{~d}$ adaptation period, a $5 \mathrm{~d}$ total collection of feces and urine was conducted. Feed refusals and feed spillage were collected, dried and weighed to calculate feed intake. Feces were collected immediately as they appeared in the metabolism crates, placed in plastic bags and stored at $20^{\circ} \mathrm{C}$. Urine was collected in a bucket placed under the metabolism crates. The bucket contained $10 \mathrm{~mL}$ of $6 \mathrm{~N} \mathrm{HCl}$ per $1,000 \mathrm{~mL}$ urine to fix nitrogen in urine. The total volume of urine was measured daily and a $10 \%$ aliquot was filtered through gauze and $50 \mathrm{~mL}$ of the mixed urine sample was transferred into a screw-capped tube and immediately stored at $-20^{\circ} \mathrm{C}$. At the end of the collection period, the

Table 1. Variation of temperature and humidity at the Fengning Experiment Base during the 12 mo of wheat storage ${ }^{1}$

\begin{tabular}{|c|c|c|c|c|c|c|c|c|c|c|c|c|c|}
\hline \multirow{2}{*}{ Variation } & \multicolumn{6}{|c|}{2013} & \multicolumn{7}{|c|}{2014} \\
\hline & 7 & 8 & 9 & 10 & 11 & 12 & 1 & 2 & 3 & 4 & 5 & 6 & 7 \\
\hline Mean temperature $\left({ }^{\circ} \mathrm{C}\right)$ & 23.50 & 22.25 & 15.08 & 7.95 & 0.13 & -7.33 & -7.37 & -6.17 & 3.56 & 12.08 & 15.93 & 19.44 & 23.20 \\
\hline Highest temperature $\left({ }^{\circ} \mathrm{C}\right)$ & 28.75 & 26.73 & 17.46 & 14.37 & 7.21 & 0.05 & -0.61 & -0.01 & 11.28 & 16.76 & 24.54 & 23.18 & 28.69 \\
\hline Lowest temperature $\left({ }^{\circ} \mathrm{C}\right)$ & 19.01 & 16.21 & 8.67 & 1.60 & -8.60 & -12.31 & -15.26 & -11.65 & -5.81 & 7.08 & 7.13 & 14.75 & 18.91 \\
\hline Medial relative humidity (\%) & 73.77 & 77.65 & 79.34 & 68.34 & 50.32 & 49.53 & 47.27 & 59.65 & 39.94 & 47.51 & 50.20 & 74.54 & 74.77 \\
\hline Highest relative humidity (\%) & 96.01 & 96.03 & 92.85 & 89.14 & 72.96 & 62.64 & 79.80 & 86.98 & 72.42 & 77.79 & 71.01 & 90.07 & 97.01 \\
\hline Lowest relative humidity (\%) & 50.63 & 53.48 & 66.00 & 46.49 & 27.25 & 38.34 & 23.54 & 16.19 & 21.99 & 19.49 & 29.81 & 59.35 & 51.63 \\
\hline
\end{tabular}

${ }^{1}$ Temperature and relative humidity were tested daily and the mean values for each month were calculated. 
Table 2. Dietary ingredients, analyzed chemical composition and available energy content of the experimental diets (as-fed basis)

\begin{tabular}{|c|c|c|c|c|c|c|c|c|}
\hline \multirow{3}{*}{ Items } & \multicolumn{8}{|c|}{ Storage time (month) } \\
\hline & \multicolumn{2}{|c|}{3} & \multicolumn{2}{|c|}{6} & \multicolumn{2}{|c|}{9} & \multicolumn{2}{|c|}{12} \\
\hline & Zhong & Shi & Zhong & Shi & Zhong & Shi & Zhong & Shi \\
\hline \multicolumn{9}{|l|}{ Ingredients (\%) } \\
\hline Variety Zhong & 97.34 & - & 97.34 & - & 97.34 & - & 97.34 & - \\
\hline Variety Shi & & 97.34 & & 97.34 & & 97.34 & & 97.34 \\
\hline Dicalcium phosphate & 0.9 & 0.9 & 0.9 & 0.9 & 0.9 & 0.9 & 0.9 & 0.9 \\
\hline Calcium carbonate & 0.9 & 0.9 & 0.9 & 0.9 & 0.9 & 0.9 & 0.9 & 0.9 \\
\hline Sodium chloride & 0.3 & 0.3 & 0.3 & 0.3 & 0.3 & 0.3 & 0.3 & 0.3 \\
\hline Choline chloride & 0.06 & 0.06 & 0.06 & 0.06 & 0.06 & 0.06 & 0.06 & 0.06 \\
\hline Vitamin-mineral premix ${ }^{1}$ & 0.5 & 0.5 & 0.5 & 0.5 & 0.5 & 0.5 & 0.5 & 0.5 \\
\hline \multicolumn{9}{|c|}{ Analyzed chemical composition (\%) } \\
\hline $\mathrm{DM}$ & 87.93 & 88.39 & 88.90 & 89.32 & 89.13 & 89.49 & 89.90 & 89.84 \\
\hline $\mathrm{CP}$ & 15.14 & 15.14 & 14.41 & 14.87 & 14.50 & 13.88 & 13.97 & 13.30 \\
\hline $\mathrm{NDF}$ & 15.28 & 14.89 & 16.82 & 15.79 & 19.54 & 18.00 & 19.10 & 20.12 \\
\hline $\mathrm{ADF}$ & 2.97 & 2.49 & 3.08 & 3.19 & 3.36 & 2.56 & 3.30 & 3.14 \\
\hline $\mathrm{EE}$ & 1.66 & 1.48 & 1.64 & 1.57 & 1.57 & 1.44 & 1.98 & 1.83 \\
\hline Ash & 4.44 & 3.97 & 4.21 & 3.80 & 4.05 & 3.71 & 4.28 & 3.95 \\
\hline Calcium & 0.69 & 0.69 & 0.71 & 0.68 & 0.69 & 0.71 & 0.71 & 0.76 \\
\hline Total phosphorus & 0.20 & 0.23 & 0.21 & 0.21 & 0.23 & 0.22 & 0.21 & 0.24 \\
\hline $\mathrm{GE}(\mathrm{MJ} / \mathrm{kg}, \mathrm{DM})$ & 18.39 & 18.38 & 18.03 & 17.96 & 16.21 & 15.51 & 17.70 & 17.65 \\
\hline
\end{tabular}

DM, dry matter; CP, crude protein; NDF, neutral detergent fiber; ADF, acid detergent fiber; EE, ether extract; GE, gross energy.

${ }^{1}$ Premix provided the following per kg of complete diet for growing pigs: vitamin $\mathrm{A}, 5,512 \mathrm{IU}$; vitamin $\mathrm{D}_{3}, 2,200 \mathrm{IU}$; vitamin E, $30 \mathrm{IU}$; vitamin $\mathrm{K}_{3}, 2.2$ $\mathrm{mg}$; vitamin $\mathrm{B}_{12}, 27.6 \mu \mathrm{g}$; riboflavin, $4 \mathrm{mg}$; pantothenic acid, $14 \mathrm{mg}$; niacin, $30 \mathrm{mg}$; choline chloride, $400 \mathrm{mg}$; folic acid, $0.7 \mathrm{mg}$; thiamin, $1.5 \mathrm{mg}$; pyridoxine, $3 \mathrm{mg}$; biotin, $44 \mu \mathrm{g}$; $\mathrm{Mn}, 40 \mathrm{mg}\left(\mathrm{MnSO}_{4}\right)$; Fe, $75 \mathrm{mg}\left(\mathrm{FeSO}_{4} \cdot \mathrm{H}_{2} \mathrm{O}\right) ; \mathrm{Zn}, 75 \mathrm{mg}\left(\mathrm{ZnSO}_{4}\right) ; \mathrm{Cu}, 100 \mathrm{mg}\left(\mathrm{CuSO}_{4} \cdot 5 \mathrm{H}_{2} \mathrm{O}\right) ; \mathrm{I}, 0.3 \mathrm{mg}(\mathrm{KI}) ; \mathrm{Se}, 0.3$ $\mathrm{mg}\left(\mathrm{Na}_{2} \mathrm{SeO}_{3}\right)$.

sampled feces and urine were pooled for each pig and subsamples were collected for chemical analysis. The subsamples of feces were dried for $72 \mathrm{~h}$ at $65^{\circ} \mathrm{C}$ and ground through a 1 -mm screen.

\section{Chemical analysis}

All chemical analyses were conducted in duplicate. Samples of wheat, diets, and feces were analyzed for dry matter (DM) (Method 930.15, AOAC 2007), ether extract (EE) (Thiex et al., 2003), crude protein (CP) (Method 984.13, AOAC 2007), ash (Method 942.05, AOAC 2007), calcium (Method 927.02, AOAC 2007), and total phosphorus (Method 984.27, AOAC 2007). Moreover, organic matter $(\mathrm{OM})$ was analyzed by 100 minus the content of ash. The neutral detergent fiber (NDF) and acid detergent fiber (ADF) were determined using fiber filter bags and fiber analyzer equipment (Fiber Analyzer, Ankom Technology, Macedon, NY, USA) following an adaptation procedure described by Van Soest et al. (1991). The concentration of NDF was analyzed using heat stable $\alpha$ amylase and sodium sulphite without correction for insoluble ash. The ADF fraction was analyzed in a separate sample. Samples of wheat, diets, feces, and urine were analyzed for gross energy (GE) via an Isoperibol Oxygen Bomb Calorimeter (Parr 6400 Calorimeter, Moline, IL,
USA). The wheat samples were also analyzed for starch (Method 948.02, AOAC 2007) and non-starch polysaccharides (NSP) which was analyzed with the derivatization of acetic anhydride by gas chromatography. Soluble non-starch polysaccharides (SNSP) and insoluble non-starch polysaccharides (INSP) were measured as the sum of their constituent sugars (rhamnose, fucose, arabinose, xylose, mannose, galactose, glucose) and uronic acid all measured by a colorimetric procedure and the sum of SNSP and INSP was recorded as total non-starch polysaccharides (TNSP). After detecting SNSP, the solid residue was dissolved by $70 \% \mathrm{H}_{2} \mathrm{SO}_{4}$ to detect INSP which did not include lignin, as lignin can't be dissolved in $70 \%$ $\mathrm{H}_{2} \mathrm{SO}_{4}$ (Englyst and Hudson, 2001).

\section{Calculations}

Energy values determined from the excretion of GE in the feces and urine were subtracted from the intake of GE to calculate DE and ME for each diet. The apparent total tract digestibility (ATTD) of chemical constituents determined from the excretion of chemical constituents in the feces were first subtracted from the intake of the chemical constituents then were divided by the intake of the chemical constituents to calculate the ATTD of the chemical constituents for each diet and wheat (Kong and Adeola, 
Table 3. Effects of storage duration on the chemical composition and energy content of wheat (DM basis)

\begin{tabular}{|c|c|c|c|c|c|c|}
\hline \multirow{2}{*}{ Item $(\%)$} & \multicolumn{4}{|c|}{ Storage time (ST month, mean \pm SD) } & \multicolumn{2}{|c|}{ Variety (mean \pm SD) } \\
\hline & 3 & 6 & 9 & 12 & Zhong & Shi \\
\hline$\overline{\mathrm{GE}}(\mathrm{MJ} / \mathrm{kg})$ & $18.49 \pm 0.02$ & $18.43 \pm 0.03$ & $18.15 \pm 0.07$ & $18.12 \pm 0.10$ & $18.30 \pm 0.19$ & $18.29 \pm 0.21$ \\
\hline $\mathrm{DM}$ & $89.03 \pm 0.62$ & $88.97 \pm 0.03$ & $89.51 \pm 0.11$ & $89.66 \pm 0.16$ & $89.10 \pm 0.38$ & $89.48 \pm 0.30$ \\
\hline $\mathrm{OM}$ & $97.57 \pm 0.20$ & $97.82 \pm 0.05$ & $97.87 \pm 0.14$ & $97.71 \pm 0.38$ & $97.62 \pm 0.22$ & $97.86 \pm 0.13$ \\
\hline $\mathrm{EE}$ & $1.88 \pm 0.02$ & $1.85 \pm 0.11$ & $1.89 \pm 0.04$ & $1.87 \pm 0.01$ & $1.91 \pm 0.03$ & $1.84 \pm 0.05$ \\
\hline $\mathrm{CP}$ & $17.57 \pm 0.25$ & $16.41 \pm 0.28$ & $16.32 \pm 0.88$ & $15.46 \pm 0.15$ & $16.63 \pm 0.77$ & $16.25 \pm 1.06$ \\
\hline Ash & $2.43 \pm 0.20$ & $2.18 \pm 0.05$ & $2.13 \pm 0.14$ & $2.29 \pm 0.38$ & $2.38 \pm 0.22$ & $2.14 \pm 0.13$ \\
\hline Starch & $58.43 \pm 0.96$ & $59.01 \pm 0.25$ & $60.00 \pm 0.11$ & $59.87 \pm 0.01$ & $59.47 \pm 0.59$ & $59.19 \pm 1.02$ \\
\hline NDF & $17.35 \pm 0.04$ & $18.50 \pm 0.62$ & $21.46 \pm 1.28$ & $22.55 \pm 0.44$ & $20.23 \pm 2.48$ & $19.70 \pm 2.52$ \\
\hline $\mathrm{ADF}$ & $3.25 \pm 0.35$ & $3.97 \pm 0.22$ & $3.42 \pm 0.53$ & $3.87 \pm 0.39$ & $3.89 \pm 0.31$ & $3.37 \pm 0.40$ \\
\hline Calcium & $0.17 \pm 0.01$ & $0.16 \pm 0.05$ & $0.16 \pm 0.01$ & $0.18 \pm 0.01$ & $0.18 \pm 0.01$ & $0.16 \pm 0.03$ \\
\hline Total phosphorus & $0.13 \pm 0.01$ & $0.12 \pm 0.01$ & $0.13 \pm 0.01$ & $0.13 \pm 0.02$ & $0.12 \pm 0.01$ & $0.13 \pm 0.02$ \\
\hline TNSP & $17.55 \pm 0.69$ & $12.30 \pm 2.82$ & $9.18 \pm 0.64$ & $9.43 \pm 0.43$ & $11.68 \pm 3.60$ & $12.54 \pm 4.45$ \\
\hline Arabinose & $3.69 \pm 0.27$ & $2.73 \pm 0.58$ & $2.01 \pm 0.11$ & $2.00 \pm 0.17$ & $2.51 \pm 0.67$ & $2.71 \pm 0.98$ \\
\hline Xylose & $5.37 \pm 0.58$ & $3.99 \pm 1.03$ & $2.97 \pm 0.16$ & $3.13 \pm 0.16$ & $3.64 \pm 0.89$ & $4.09 \pm 1.41$ \\
\hline Ara/Xyl ratio & $0.77 \pm 0.03$ & $0.77 \pm 0.04$ & $0.75 \pm 0.01$ & $0.74 \pm 0.02$ & $0.77 \pm 0.02$ & $0.74 \pm 0.01$ \\
\hline Mannose & $3.04 \pm 0.26$ & $1.44 \pm 0.89$ & $0.66 \pm 0.01$ & $0.74 \pm 0.04$ & $1.35 \pm 1.25$ & $1.59 \pm 1.06$ \\
\hline INSP & $15.36 \pm 0.73$ & $10.32 \pm 2.61$ & $7.48 \pm 0.76$ & $7.44 \pm 0.35$ & $9.80 \pm 3.40$ & $10.54 \pm 4.29$ \\
\hline Arabinose & $3.29 \pm 0.27$ & $2.39 \pm 0.48$ & $1.68 \pm 0.14$ & $1.64 \pm 0.15$ & $2.17 \pm 0.64$ & $2.33 \pm 0.95$ \\
\hline Xylose & $4.80 \pm 0.55$ & $3.50 \pm 0.90$ & $2.52 \pm 0.17$ & $2.58 \pm 0.13$ & $3.15 \pm 0.85$ & $3.55 \pm 1.36$ \\
\hline Ara/Xyl ratio & $0.77 \pm 0.03$ & $0.77 \pm 0.04$ & $0.74 \pm 0.01$ & $0.70 \pm 0.03$ & $0.76 \pm 0.03$ & $0.73 \pm 0.03$ \\
\hline Mannose & $2.65 \pm 0.18$ & $1.07 \pm 0.91$ & $0.41 \pm 0.03$ & $0.40 \pm 0.02$ & $1.00 \pm 1.18$ & $1.26 \pm 1.04$ \\
\hline SNSP & $1.87 \pm 0.04$ & $1.69 \pm 0.22$ & $1.43 \pm 0.16$ & $1.74 \pm 0.06$ & $1.63 \pm 0.26$ & $1.73 \pm 0.14$ \\
\hline Arabinose & $0.40 \pm 0.01$ & $0.34 \pm 0.10$ & $0.33 \pm 0.02$ & $0.37 \pm 0.02$ & $0.34 \pm 0.06$ & $0.38 \pm 0.03$ \\
\hline Xylose & $0.57 \pm 0.03$ & $0.50 \pm 0.14$ & $0.45 \pm 0.02$ & $0.55 \pm 0.02$ & $0.49 \pm 0.08$ & $0.54 \pm 0.06$ \\
\hline Ara/Xyl ratio & $0.78 \pm 0.04$ & $0.78 \pm 0.01$ & $0.80 \pm 0.03$ & $0.75 \pm 0.01$ & $0.78 \pm 0.02$ & $0.78 \pm 0.04$ \\
\hline Mannose & $0.39 \pm 0.08$ & $0.38 \pm 0.02$ & $0.26 \pm 0.03$ & $0.35 \pm 0.03$ & $0.35 \pm 0.09$ & $0.33 \pm 0.04$ \\
\hline
\end{tabular}

SD, Standard deviation; GE, gross energy; DM, dry matter; OM, organic matter; EE, ether extract; CP, crude protein; NDF, neutral detergent fiber; ADF, acid detergent fiber; TNSP, total non-starch polysaccharides; INSP, insoluble non-starch polysaccharides; SNSP, soluble non-starch polysaccharides.

2014). The DE and ME in the wheat diets were divided by 0.9734 to calculate the DE and ME of the wheat itself.

\section{Statistical analysis}

All data were analyzed as a $2 \times 4$ factorial according to the analysis of variance procedure of SAS (SAS Institute; Cary, NC, USA) to evaluate the main effects of storage time, wheat variety and their interaction. The experimental unit was the pig. The statistical model included the fixed effects of wheat variety and storage time as well as the random effect of pig. The replication unit was the pig. All results are reported as least squares means. Orthogonal polynomial contrasts were used to test for linear and quadratic effects of storage time on chemical composition and energy digestibility of wheat. The level of significance adopted was $5 \%$.

\section{RESULTS}

\section{Chemical composition of wheat}

With an extension of storage duration from 3 mo to 12 mo, the GE and CP of the wheat decreased by $2.0 \%$ and
$12.01 \%$, respectively, while the concentration of NDF, ADF and starch content increased by $30.26 \%, 19.08 \%, 2.46 \%$, respectively. The DM, EE, ash, calcium and phosphorus contents remained relatively stable during storage. Total non-starch polysaccharide, total arabinose, total xylose and total mannose contents decreased by $46.27 \%, 45.80 \%$, $41.71 \%$, and $75.66 \%$, respectively. The main contributors to this fluctuation were the INSP, insoluble arabinose, xylose and mannose, as all of these parameters were decreased by $51.56 \%, 50.15 \%, 46.25 \%$, and $84.91 \%$ within the storage time, while the SNSP (soluble arabinose, xylose, and mannose) were relatively stable. There were no significant differences between the two wheat varieties with the exception of ADF which was approximately $13.37 \%$ lower in Shi (Table 3).

\section{Energy and nutrient digestibility and concentration of digestible and metabolizable energy}

The feed intake, GE intake, fecal excretion of GE and the DE, ME, and ATTD of GE in wheat diets decreased $(p<0.01)$ linearly with an extension of storage time (Table 4). Urinary excretion of GE changed (quadratic, $p<0.05$ ) 
Table 4. Concentration of DE and ME, and ATTD of energy in diets (as-fed basis)

\begin{tabular}{|c|c|c|c|c|c|c|c|c|c|c|c|c|c|}
\hline \multirow{2}{*}{ Items } & \multicolumn{4}{|c|}{ Storage time (month) } & \multirow{2}{*}{ SEM } & \multicolumn{2}{|c|}{ Variety } & \multirow{2}{*}{ SEM } & \multicolumn{5}{|c|}{$p$-value } \\
\hline & 3 & 6 & 9 & 12 & & Zhong & Shi & & ANOVA & Linear & Quadratic & Variety & Variety $\times \mathrm{ST}$ \\
\hline Feed intake $(\mathrm{kg} / \mathrm{d})$ & 2.21 & 1.79 & 2.11 & 1.41 & 0.10 & 1.84 & 1.90 & 0.07 & $<0.01$ & $<0.01$ & 0.16 & 0.44 & 0.30 \\
\hline GE intake $(\mathrm{MJ} / \mathrm{d})$ & 35.78 & 28.78 & 33.53 & 22.37 & 1.54 & 29.45 & 30.63 & 1.06 & $<0.01$ & $<0.01$ & 0.21 & 0.40 & 0.32 \\
\hline GE in feces $(\mathrm{MJ} / \mathrm{d})$ & 3.87 & 3.06 & 3.93 & 3.25 & 0.21 & 3.50 & 3.54 & 0.15 & $<0.01$ & 0.29 & 0.71 & 0.80 & 0.76 \\
\hline GE in urine $(\mathrm{MJ} / \mathrm{d})$ & 0.92 & 0.52 & 0.66 & 0.98 & 0.11 & 0.85 & 0.69 & 0.07 & $<0.01$ & 0.48 & $<0.01$ & 0.14 & 0.65 \\
\hline $\mathrm{DE}(\mathrm{MJ} / \mathrm{kg})$ & 14.45 & 14.34 & 14.04 & 13.59 & 0.06 & 14.07 & 14.13 & 0.04 & $<0.01$ & $<0.01$ & 0.01 & 0.38 & 0.36 \\
\hline $\mathrm{ME}(\mathrm{MJ} / \mathrm{kg})$ & 14.02 & 14.04 & 13.72 & 12.91 & 0.10 & 13.60 & 13.75 & 0.07 & $<0.01$ & $<0.01$ & $<0.01$ & 0.16 & 0.62 \\
\hline ATTD of GE (\%) & 89.11 & 89.40 & 88.23 & 85.58 & 0.40 & 88.01 & 88.15 & 0.27 & $<0.01$ & $<0.01$ & $<0.01$ & 0.73 & 0.48 \\
\hline
\end{tabular}

DE, digestible energy; ME, metabolizable energy; ATTD, apparent total tract digestibility; SEM, standard error of the mean; ANOVA, analysis of variance; ST, storage time; GE, gross energy.

with increased storage time. There was no significant effect of variety and variety by storage time on parameters in Table 4. The DE, ME and digestibility of GE, DM, ADF, CP, $\mathrm{EE}, \mathrm{OM}$, and $\mathrm{ME}$ decreased significantly with increasing storage time, and the digestibility of NDF changed in a quadratic manner $(\mathrm{p}<0.01)$ (Table 5).

\section{DISCUSSION}

\section{Chemical composition of wheat}

It has been reported that fluctuations in temperature and humidity result in considerable nutrient loss in wheat (Rehman, 2006). According to a previous study, no significant biochemical changes occurred to wheat during 6 mo of post-harvest storage at $10^{\circ} \mathrm{C}$, but significant losses in lysine occurred at $25^{\circ} \mathrm{C}$ (Rehman and Shah, 1999). In the current study, the environmental temperature ranged from $15^{\circ} \mathrm{C}$ to $25^{\circ} \mathrm{C}$ for the first 3 months of storage, then decreased to less than $10^{\circ} \mathrm{C}$ during 6 to 9 mo of storage, and subsequently increased from $15^{\circ} \mathrm{C}$ to $25^{\circ} \mathrm{C}$ during 9 to 12 mo of storage. Therefore, changes in environmental temperature may be the main reason for the reduction in the concentration of CP.

The total starch content of fresh waxy corn remained stable after $4 \mathrm{~d}$ storage at $20^{\circ} \mathrm{C}$ with the amylopectin content decreasing and the amylose content increasing (Gong and Chen, 2013). In addition, Rehman and Shah (1999) reported that the total amylose content in wheat remained unchanged during 6 mo of storage because of a slow, but steady decrease in water soluble amylose and an increase in insoluble amylose at $25^{\circ} \mathrm{C}$. However, very little information is available on the variation of total starch during the postharvest storage of fresh wheat. Therefore, it is possible that the increase in starch concentration observed in this experiment may have been the result of an increase in insoluble amylose content. Our results contrast with previous data indicating that wheat grains harvested and stored at ambient temperature for more than 4 mo had decreased total starch and ADF but increased CP (Jood et al., 1993; Kim et al., 2003). However, this discrepancy may be due to the relatively short post-harvest period in the earlier studies as the data in the present investigation indicate that the chemical composition and the available nutrients in the two wheat varieties did not change during storage for 3 to 6 mo. The CP content in wheat has been shown to be inversely correlated to total starch content $(r=-0.779$, $\mathrm{p}<0.01)$ and soluble NSP content $(\mathrm{r}=-0.606, \mathrm{p}<0.01)(\mathrm{Kim}$ et al., 2003), and our data are in agreement with the data

Table 5. Digestibility of chemical constituents of wheat after different storage times when fed to finishing pigs (as-fed basis)

\begin{tabular}{|c|c|c|c|c|c|c|c|c|c|c|c|c|c|}
\hline \multirow{2}{*}{ Items } & \multicolumn{4}{|c|}{ Storage time (month) } & \multirow{2}{*}{ SEM } & \multicolumn{2}{|c|}{ Variety } & \multirow{2}{*}{ SEM } & \multicolumn{5}{|c|}{ p-value } \\
\hline & 3 & 6 & 9 & 12 & & Zhong & Shi & & ANOVA & Linear & Quadratic & Variety & Variety $\times \mathrm{ST}$ \\
\hline$\overline{\mathrm{DE}(\mathrm{MJ} / \mathrm{kg})}$ & 14.99 & 14.88 & 14.57 & 14.13 & 0.06 & 14.60 & 14.69 & 0.04 & $<0.01$ & $<0.01$ & $<0.01$ & 0.12 & 0.29 \\
\hline $\mathrm{ME}(\mathrm{MJ} / \mathrm{kg})$ & 14.61 & 14.61 & 14.28 & 13.50 & 0.09 & 14.16 & 14.34 & 0.06 & $<0.01$ & $<0.01$ & $<0.01$ & 0.06 & 0.70 \\
\hline GE $(\%)$ & 90.00 & 90.33 & 89.15 & 86.62 & 0.35 & 88.87 & 89.17 & 0.25 & $<0.01$ & $<0.01$ & $<0.01$ & 0.35 & 0.34 \\
\hline $\mathrm{CP}(\%)$ & 91.78 & 92.54 & 90.17 & 88.22 & 0.52 & 91.09 & 90.27 & 0.36 & $<0.01$ & $<0.01$ & 0.01 & 0.15 & 0.03 \\
\hline DM (\%) & 88.93 & 89.40 & 88.52 & 85.81 & 0.38 & 87.94 & 88.39 & 0.27 & $<0.01$ & $<0.01$ & $<0.01$ & 0.22 & 0.45 \\
\hline OM (\%) & 92.12 & 92.57 & 91.69 & 89.85 & 0.27 & 91.41 & 91.70 & 0.19 & $<0.01$ & $<0.01$ & 0.01 & 0.27 & 0.26 \\
\hline EE (\%) & 52.17 & 51.19 & 38.40 & 38.49 & 1.83 & 46.35 & 43.77 & 1.27 & $<0.01$ & $<0.01$ & 0.77 & 0.19 & 0.12 \\
\hline $\operatorname{ADF}(\%)$ & 35.67 & 49.35 & 34.96 & 25.81 & 2.24 & 37.52 & 35.38 & 1.56 & $<0.01$ & $<0.01$ & $<0.01$ & 0.35 & 0.05 \\
\hline NDF (\%) & 69.43 & 72.66 & 72.77 & 67.43 & 1.01 & 69.97 & 71.18 & 0.70 & $<0.01$ & 0.20 & $<0.01$ & 0.24 & 0.10 \\
\hline $\begin{array}{l}\text { Metabolizability } \\
\text { of energy (\%) }\end{array}$ & 89.77 & 90.16 & 88.97 & 86.23 & 0.37 & 88.60 & 88.96 & 0.26 & $<0.01$ & $<0.01$ & $<0.01$ & 0.30 & 0.39 \\
\hline
\end{tabular}

DM, dry matter; SEM, standard error of the mean; ANOVA, analysis of variance; ST, storage time; DE, digestible energy; ME, metabolizable energy; GE, gross energy; $\mathrm{CP}$, crude protein; $\mathrm{OM}$, organic matter; EE, ether extract; $\mathrm{ADF}$, acid detergent fiber.; NDF, neutral detergent fiber. 
reported by Kim et al. (2003). A negative correlation between $\mathrm{CP}$ and total starch has also been previously observed in wheat $(\mathrm{r}=-0.555)$ (Metayer et al., 1993; Choct et al., 1999).

The EE of the wheat obtained in this study $(1.91 \% \mathrm{DM}$ in Zhong and $1.84 \% \mathrm{DM}$ in Shi) were close to the value reported by NRC (2012), and the content of EE was relatively constant during the 12 mo storage period.

Although NDF and NSP are both fiber measured by different methods. In this study the NDF increased and the NSP decreased with increasing storage time. Cell wall mosaics protein or cell wall protein connected with the NSP and lignin can't be removed when tested with NDF, monogastric animals had low digestibility of this protein (Annison, 1993). This protein is not included in the calculations of NSP, which is based only on the constituent sugars. This may be the reason for the inverse relationship between NDF and INSP content.

The decrease in insoluble NSP after 6 months of storage is in agreement with the results reported by Kim et al. (2003). The reason for this change may be due to the ability of the endogenous glycanases of the grain to break down NSP during storage (Choct and Hughes, 1997). Variety, location and year of harvest may have an effect on the NSP content of wheat (Knudsen, 1997; Zijlstra et al., 1999; Kim et al., 2005).

Wheat is typically divided into "soft-wheat" or "hardwheat" (Gutierrez-Alamo et al., 2008). The two varieties used in this experiment were both white hard winter wheat and planted in the same area. The only difference between the two wheat varieties occurred was in the content of ADF.

\section{Energy values and variation of wheat}

The DE content of wheat stored for 3 mo was the highest and decreased by $2.81 \%$ and $5.74 \%$ after 9 and 12 mo of storage $(p<0.05)$. Similarly, storage of wheat for 9 and 12 mo significantly decreased the ME of wheat by $2.26 \%$ and $7.60 \%(\mathrm{p}<0.05)$. The highest DE $(14.99 \mathrm{MJ} / \mathrm{kg}$ $\mathrm{DM})$ and $\mathrm{ME}(14.61 \mathrm{MJ} / \mathrm{kg} \mathrm{DM})$ of wheat determined at 3 mo of storage in this study were lower than the values reported by $\mathrm{NRC}$ (2012) $(\mathrm{DE}=15.64 \mathrm{MJ} / \mathrm{kg} \mathrm{DM}, \mathrm{ME}=$ $15.17 \mathrm{MJ} / \mathrm{kg} \mathrm{DM}$ ), but within the range of values from other previous reports (Kopinski, 1997; Wiseman, 2000).

Scott and Pierce (2001) reported that 6 mo storage of wheat improved poultry performance. Cadogan et al. (2003) reported that the feed intake and daily gain of young pigs improved when fed wheat was stored for 10 mo. However, there was no correlation between wheat apparent ME and animal performance (Rose and Bedford, 1995; Scott et al., 1998; Steenfeldt, 2001). And changes in DE and ME are positively correlated with a change in $\mathrm{CP}$ and negatively correlated with a change in NDF (Batterham et al., 1980; Zijlstra et al., 1999). Thus the decrease of DE and ME in wheat in the current work may be the result of the decrease of CP and increase of NDF (Regmi et al., 2009).

\section{Chemical component digestibility and variation of wheat}

The ATTD of GE determined in this research $(86.62 \%$ to $90.00 \%$ ), were consistent with values of $85 \%$ to $90 \%$ reported by Smith et al. (1987), Noblet and Perez (1993) and Wiseman (2000). For practical purposes, the concentration of crude fiber represents a reasonable predictor for the digestibility coefficient of energy (Noblet and Perez, 1993). The decline in apparent digestibility of energy and other chemical constituents (OM, CP, DM) may be due to the increasing NDF and ADF content with increasing storage time.

The ATTD of CP observed in this experiment was greater, as $50.3 \%$ to $82.3 \%$ obtained by Anderson and Bell (1983). This may be the result of the fact that the pigs used in the present study had higher BW $(60 \mathrm{~kg})$ than Anderson and Bell's (40 kg). In this study, the digestibility of CP decreased significantly $(\mathrm{p}<0.01)$ by $4.67 \%$ from $6 \mathrm{mo}$ storage to 12 mo storage. In vitro protein digestibility of new season rice, maize and wheat grains decreased by $8.69 \%, 9.09 \%$, and $9.45 \%$ after 6 mo storage at $25^{\circ} \mathrm{C}$, respectively (Rehman, 2006). Decreased protein content or increased crude fiber content tended to decrease the apparent digestibility of protein by pigs (Bell et al., 1983). In particular, the content CP decreased and NDF increased simultaneously with increasing storage time in present study.

This finding is in line with previous studies which have shown that an increase in the dietary fiber content may decrease the digestibility of dietary chemical constituents and energy (Noblet and Perez, 1993; Knudsen and Jørgensen, 2001). The most probable explanation for these results was that significant quantities of the dietary constituents in the feed were protected from digestion by the fibrous material naturally occurring in the feed (Lloyd and Crampton, 1955).

\section{CONCLUSION}

Under the conditions of this research, the content of GE, $\mathrm{CP}$, and NSP in wheat decreased, but the content of NDF, $\mathrm{ADF}$, and starch in wheat increased during storage. The DE, $\mathrm{ME}$ and digestibility of GE, CP, EE, DM, OM, ADF, and NDF as well as the ME content of wheat decreased when the wheat was stored for more than $6 \mathrm{mo}$. The decreased DE and $\mathrm{ME}$ of wheat for finishing pigs after one year of storage was mainly due to the decreased digestibility of their chemical constituents. Because of storage conditions and variety of wheat, there are limitations on application of these results. Therefore, more research is needed to confirm the results of the present study using wheat obtained over a 
number of years and different geographical locations.

\section{ACKNOWLEDGMENTS}

This research was financially supported by the Special Public Sector Fund in Agriculture (200903006).

\section{REFERENCES}

Anderson, D. M. and J. M. Bell. 1983. The digestibility by pigs of dry matter, energy, protein and amino acids in wheat cultivars. II. Fifteen cultivars grown in two years, compared with Bonanza and Fergus barleys, and 3CW-Grade hard red spring wheat. Can. J. Plant Sci. 63:393-406.

Annison, G. 1993. The role of wheat non-starch polysaccharides in broiler nutrition. Aust. J. Agric. Res. 44:405-422.

AOAC International. 2007. Official Methods of Analysis. 18th ed. AOAC Int., Arlington, VA, USA.

Batterham, E. S., C. E. Lewis, R. F. Lowe, and C. J. McMillan. 1980. Digestible energy content of cereals and wheat byproducts for growing pigs. Anim. Prod. 31:259-271.

Bell, J. M., A. Shires, and M. O. Keith. 1983. Effect of hull and protein contents of barley on protein and energy digestibility and feeding value for pigs. Can. J. Anim. Sci. 63:201-211.

Cadogan, D. J., M. Choct, and R. G. Campbell. 2003. Effects of storage time and exogenous xylanase supplementation of new season wheats on the performance of young male pigs. Can. J. Anim. Sci. 83:105-112.

Choct, M. and B. Hughes. 2000. The new season grain phenomenon: The role of endogenous glycanases in the nutritive value of cereal grains in broiler chickens. Rural Industries Research and Development Corporation, Armidale, Australia. pp. 1-49.

Choct, M. and R. J. Hughes. 1997. The nutritive value of new season grains for poultry. In: Recent Advancements in Animal Nutrition in Australia (Eds. J. L. Corbett, M. Choct, J. V. Nolan, and J. B. Rowe). University of New England, Armidale, Australia. pp. 146-150.

Choct, M. and R. J. Hughes. 1999. Effect of storage on the value of cereal grains for poultry. In: Proceedings of the Eleventh Australian Poultry and Feed Convention (Ed. M. Murrell). Gold Coast, Australia. pp. 223-239.

Choct, M., R. J. Hughes, and G. Annison. 1999. Apparent metabolisable energy and chemical composition of Australian wheat in relation to environmental factors. Aust. J. Agric. Res. 50:447-451.

Dusel, G., H. Kluge, K. Glaser, O. Simon, G. Hartmann, J. V. Lengerken, and H. Jeroch. 1997. An investigation into the variability of extract viscosity of wheat-relationship with the content of non-starch-polysaccharide fractions and metabolisable energy for broiler chickens. Archiv. Tierernaehr. 50:121-135.

Englyst, H. N. and G. J. Hudson. 2001. Dietary fiber analysis as nonstarch polysaccharides. In: Dietray Fiber in Human Nutrition (Ed. G. A. Spiller). 3rd. CRC Press, Boca Raton, FL, USA. pp. 67-82.

Gong, K. J. and L. R. Chen. 2013. Characterization of carbohydrates and their metabolizing enzymes related to the eating quality of postharvest fresh waxy corn. J. Food Biochem.34:619-627.

Gutierrez-Alamo, A., P. Perez de Ayala, M. W. A. Verstegen, L. A. D. Hartog, and M. J. Villamide. 2008. Variability in wheat: Factors affecting its nutritional value. World Poult. Sci. J. 64:20-39.

Huyghebaert, G. and F. J. Schoner. 1999. Influence of storage and addition of enzyme on metabolisable energy content of wheat 1. Impact of storage and enzyme addition. Archiv fur Geflugelkunde 63:13-20.

Jood, S., A. C. Kapoor, and R. Singh. 1993. Available carbohydrates of cereal grains as affected by storage and insect infestation. Plant Foods Hum. Nutr. 43:45-54.

Kim, J. C., B. P. Mullan, P. H. Simmins, and J. R. Pluske. 2003. Variation in the chemical composition of wheats grown in Western Australia as influenced by variety, growing region, season, and post-harvest storage. Aust. J. Agric. Res. 54:541550.

Kim, J. C., P. H. Simmins, B. P. Mullan, and J. R. Pluske. 2005. The digestible energy value of wheat for pigs, with special reference to the post-weaned animal. Anim. Feed Sci. Technol. 122:257-287.

Knudsen, K. E. B. 1997. Carbohydrate and lignin contents of plant materials used in animal feeding. Anim. Feed Sci. Technol. 67:319-338.

Knudsen, K. E. B. and H. Jørgensen. 2001. Intestinal degradation of dietary carbohydrates-from birth to maturity. In: Digestive Physiology of Pigs (Eds. J. E. Lindberg, and B. Ogle). CABI Publishing, Wallingford, UK. pp. 109-120.

Kong, C. and O. Adeola. 2014. Invited review: Evaluation of amino acid and energy utilization in feedstuff for swine and poultry diets. Asian Australas. J. Anim. Sci. 27:917-925.

Kopinski, J. 1997. Characteristics of cereal grains affecting energy value. In: Pig Research and Development Corporation Final Report DAQ35P. Pig Research and Development Corporation, Canberra, Australia.

Lloyd, L. E. and E. W. Crampton. 1955. The apparent digestibility of the crude protein of the pig ration as a function of its crude protein and crude fiber content. J. Anim. Sci.14:693-699.

Metayer, J. P., F. Grosjean, and J. Castaing. 1993. Study of variability in french cereals. Anim. Feed Sci. Technol. 43:87108

National Research Council. 1998. Nutrient Requirements of Swine. 10th Ed. Natl. Acad. Press, Washington, DC, USA.

National Research Council. 2012. Nutrient Requirements of Swine 11th Ed. Natl. Acad. Press, Washington, DC, USA.

Noblet, J. and J. M. Perez. 1993. Prediction of digestibility of nutrients and energy values of pig diets from chemical analysis. J. Anim. Sci. 71:3389-3398.

Regmi, P. R., N. S. Ferguson, and R. T. Zijlstra. 2009. In vitro digestibility techniques to predict apparent total tract energy digestibility of wheat in grower pigs. J. Anim. Sci. 87:36203629.

Rehman, Z. U. 2006. Storage effects on nutritional quality of commonly consumed cereals. Food Chem. 95:53-57.

Rehman, Z. U. and W. H. Shah. 1999. Biochemical changes in wheat during storage at three temperatures. Plant Foods Hum. 
Nutr. 54:109-117.

Rose, S. P. and M. Bedford. 1995. Relationship between the metabolisable energies of wheat samples and the productive performance of broilers. Br. Poult. Sci. 36:864-865.

Scott, T. A. and A. B. Pierce. 2001. The effect of storage of cereal grain and enzyme supplementation on measurements of AME and broiler chick performance. Can. J. Anim. Sci. 81:237-243.

Scott, T. A., F. G. Silversides, H. L. Classen, M. L. Swift, and M. R. Bedford. 1998. Comparison of sample source (excreta or ileal digesta) and age of broiler chick on measurement of apparent digestible energy of wheat and barley. Poult. Sci. 77:456-463.

Smith, W. C., P. J. Moughan, G. Person, and K. A. C. James. 1987. Comparative bioavailable energy values of five ground cereal grains measured with growing rats and pigs. Anim. Feed Sci. Technol. 18:143-150.
Steenfeldt, S. 2001. The dietary effect of different wheat cultivars for broiler chickens. Br. Poult. Sci. 42:595-609.

Thiex, N. J., S. Anderson, and B. Gildemeister. 2003. Crude fat, diethyl ether extraction, in feed, cereal grain, and forage (Randall/Soxtec/Submersion method): Collaborative study. J. AOAC. Int. 86:888-898.

Van Soest, P. J., J. B. Robertson, and B. A. Lewis. 1991. Methods for dietary fiber, neutral detergent fiber, and nonstarch polysaccharides in relation to animal nutrition. J. Dairy Sci. 74:3583-3597.

Wiseman, J. 2000. Correlation between physical measurements and dietary energy values of wheat for poultry and pigs. Anim. Feed Sci. Technol. 84:1-11.

Zijlstra, R. T., C. F. M. de Lange, and J. F. Patience. 1999. Nutritional value of wheat for growing pigs: Chemical composition and digestible energy content. Can. J. Anim. Sci. 79:187-194. 